This is the peer reviewed version of the following article:

Geertman, Stephanie, and Julie-Anne Boudreau. 2018. "“Life as Art":

Emerging Youth Networks in Hanoi and the Tree Hug Movement."

City \& Society 30 (2): 210-236. doi: 10.1111/ciso.12162

which has been published in final form at

https://doi.org/10.1111/ciso.12162.

This article may be used for non-commercial purposes in accordance with Wiley Terms and Conditions for Self-Archiving 


\title{
"Life as Art": Emerging Youth Networks in Hanoi and the Tree Hug Movement
}

\author{
Stephanie Geertman \\ Independent Scholar \\ Julie-Anne Boudreau \\ Centre Urbanisation Culture Société
}

\begin{abstract}
Drawing on two years of fieldwork in Hanoi, this paper explores what it means to be young and politically engaged in a post-reform communist city that has recently integrated into the global economy and international culture. We suggest that many young people's desire to assert more playful urban lifestyles and to live their "lives as art" contributed to their engagement in the Tree Hug Movement that swept Hanoi in the spring of 2015. Using interviews with youth who were active in the Tree Hug Movement and ethnographic observations of how young people succeeded in "being" in public spaces, this paper suggests that play can easily transform into politics. Looking at the intertwinement of digital and physical urban spaces, we note how youth mobilized the Tree Hug Movement by drawing upon the same non-confrontational tactics that they first developed to carve out a space for themselves in urban public spaces: "quiet encroachment," affective arguments, and conflict avoidance. This, we conclude, contributed to creating new forms of political engagement that can be observed elsewhere in the global urban world. [Youth Movement; Public Space; Wired Generation; Tree Hug Movement; Hanoi]
\end{abstract}




\section{Introduction}

We try to keep every march friendly. We do not want any violence against the government. We know that will not work. ... We need to take it step-by-step and softly. You can't compare it to the Umbrella Revolution [in Hong Kong], though we have read a lot about them and learned a lot from them. The way they organized a peaceful march; we believe they got a lot more support from that. (Hiên, interview, June 26, 2015¹)

At the time of our fieldwork, Hiên was twenty-two years old and studying economics. She had traveled overseas only once, to Singapore, but had plans to study abroad the following year. Throughout the course of her studies, Hiên had gradually become more involved in the Tree Hug Movement in Hanoi. Like thousands of others, Hiên had met and communicated online with other like-minded people, while also using the physical space of the city for silent protest. During the Tree Hug Movement, students mobilized and marked trees scheduled to be cut down with posters that said: “Tôi là một cái cây khỏe mạnh. Đừng chặt tôi” (I am a healthy tree. Don’t cut me down). While the police took down these posters quickly, videos and photos of the events continued to be posted on social media.

The Tree Hug Movement began with protest groups on Facebook. In March 2015, citizens in the capital of Vietnam began to oppose a project of the Hanoi People's Committee (hereafter referred to as $H P C$ ) to replace 6,708 trees. On March 17, 2015, the Facebook page 6,700 nguoòi vì 6,700 cây xanh (hereafter referred to using our English translation 6,700 People for 6,700 Green Trees) was spontaneously created by Trà, a worried young mother. She sought 6,700 page "likes"; instead, the page accumulated 55,000 likes in a single day. The following day, the Facebook group 6700 cây xanh (hereafter referred to using our English translation 6700 Green Trees) was initiated by a leader of the Architecture Cinema Club, with the aim of making a documentary on 
the topic. Within twenty-four hours, it had 4,500 members. While these first two online networks focused solely on trees, another Facebook group, Vì một Hà Nội xanh (hereafter referred to using our English translation For a Green Hanoi), was formed on March 30, 2015 by environmental and political activists. This group demanded that HPC be more transparent and accountable with regard to the process of cutting the trees and, more generally, demonstrate an increased respect for citizen rights. At the peak of the Tree Hug Movement, a diverse online community had emerged, amounting to a total population of approximately $90,000 .^{2}$

This politicization of the Vietnamese people, and their use of the streets of Hanoi for their silent protests, should be understood in the context of a transforming sociopolitical landscape. During the Sixth Communist Party Congress in 1986, policy changes (known as đổi móti) were introduced to gradually insert the socialist system of governance into the world market. Exposed to international standards and values, new rights were granted to protect freedom of expression in the 1992 Constitution (amended in 2013). This eventually led to a more individualized youth culture, later helped by new information technologies. The young people with whom we conducted fieldwork were all born after 1986. As we will argue in this paper, they represent a generational rupture because they grew up in a wired world. To describe how these connections following the state's opening to the world economy have affected their worldviews, young people in Hanoi repeatedly speak of "cuộc sống là nghệ thuật" (living your life as art.) Minh, who is nineteen years old, defines this lifestyle as:

Living in an elevated manner, with freedom, enjoyment, and chasing dreams; without deprivation and not only living for yourself but also for others. . . I have always lived my life as art, with freedom and an easygoing mindset (sống tụ do thoải mái), so I don't know what it's like to not live life as art. But it really helps me when my mood is unstable and my mind is messy. (Interview, June 22, 2015) 
The Vietnamese criminal code, however, continues to prohibit public critique of the government. The Communist Party of Vietnam controls all printed media and sets press guidelines. Although citizens have the right to complain against administrative officials (a constitutional right granted in the 1959, 1980, and 1992 constitutions), they are not allowed to complain about normative documents issued by the state. Generally, it is very difficult to exercise this right in Vietnam (The Asia Foundation 2009). Citizen political participation is further limited by limited access to information, and debates about new policies and legislation are rarely open to the public. A national police force still monitors people's ideas (at home and in workplaces) on a daily basis. Young people are currently attempting to create more space for public critique in a subtle, non-combative way.

Despite these constraints, the country has been witnessing the consolidation of its civil society, including the increasing visibility of political dissidents, since the mid-1990s. There is evidence of increased political participation in the fields of environmental management (Parenteau and Nguyen 2010), land-disputes (Wells-Dang 2010), as well as a general rise in democracy advocacy (Kerkvliet 2015), and human rights activism (Bùi Hai Thiêm 2015). In particular, the media has taken a more active role as public watchdog on cases of corruption, environmental damage, and land use (Wells-Dang 2010). Although the printed media is still censored, editors and journalists increasingly find ways to work around the state's power structure (Trần Hữu Phúc Tiến 2002). In recent years, the Internet has become a major vehicle for the consolidation of an independent civil society that is more difficult to control (Thomas 2001; Kürfurst 2012; Sharbaugh and Nguyen 2014; Vũ Quốc Cường et al. 2016). The first massive Internet mobilization that brought citizens to the streets - a mobilization that was facilitated via Facebook - took place on June 5, 2011, marking the first anti-China protest in Vietnam. These protests were in response to the events of May 26, 2011, when Chinese maritime surveillance 
vessels cut the seismic cables of two Vietnamese vessels in the South China Sea (Radio Free Asia 2011; Reuters 2011; BBC 2011). In 2012, 2014, 2016, and 2017, nationwide protests against China's naval operations in the South China Sea continued (BBC 2012; BBC 2014; Guardian 2016; Reuters 2017). In spring 2016, thousands of people took to the streets again to demand government answers regarding mass sea fish deaths, alleged by many of the protestors to have been caused by a Taiwanese-owned steel plant (BBC 2016; Reuters 2016; Aljazeera 2016). The Tree Hug Movement was among the groups that took part in these recent Facebook-driven political mobilizations in Vietnam.

The Tree Hug Movement arose in response to an urban modernization project that started with Decision No. 19/2010/QD-UBND signed on May 14, 2010, regulating green spaces in Hanoi. Decision No. 6816/QD-UNND—signed on November 11, 2013 by the Vice Chairman of HPC — called for the replacement of 6,708 trees across 190 streets in Hanoi. Both decisions were not publicized in the media. The public first took notice in January 2015 when hundreds of large, historical elm trees were cut down to make space for an elevated railway. This led to an emotional outcry on social media. On March 10, 2015, HPC informed the official (statecontrolled) media that cutting the trees was part of the city's policy "2015-Year of Urban Order and Civilization." The policy is illustrative of the party's decision to modernize Vietnamese cities and "civilize society" (Geertman 2007, 208; Harms 2009; Schwenkel 2012).

Almost a decade ago, the Save the Unification Park campaign prevented the transformation of the largest green area in the city (Công Viên Thống Nhất) into a theme park (Wells-Dang 2010; Söderström and Geertman 2013). That development was halted through an emotional outcry similar to what was witnessed during the Tree Hug Movement. However, it was a campaign launched by formal organizations, such as the Vietnamese Urban Planning Association and the Canadian NGO HealthBridge, who jointly created a formal platform to 
counter the plan. No protests took place in the park itself or on the streets. Instead, action was oriented towards direct communication with government bodies, working with professional associations, and launching a public campaign involving traditional and electronic media (WellsDang 2010; Söderström and Geertman 2013). The Tree Hug Movement operated differently: it started online with a young woman spontaneously creating a Facebook page. An online community quickly formed, including journalists, intellectuals, lawyers, civil servants, artists, human rights activists, and many students. The movement creatively organized six "Peaceful Walks," a cycling tour "Cycling for Trees," and a "Tree Hug Picnic.” In addition, an online petition reaching over 22,000 signatures in one day was sent to HPC. Those in the movement who were architects started coordinating the mapping and monitoring of the tree cutting. They shared their findings online, and as such provided the public with their comments on HPC's process of selecting and cutting the trees. Famous singers participated in a wave of cover songs, with the message "xin đùng đốn cay" (please don't cut the trees). Artists and poets produced work promoting the trees as living creatures, and poets wrote about them as historical symbols for the citizens of Hanoi.

HPC responded that the removal of healthy trees would be paused for further investigation. However, according to a newspaper article, HPC argued that they still needed to continue cutting down the trees that were sick and dead (Tuổi Trẻ 2015). This did not satisfy the protesters, who posted on Facebook pictures of healthy trees still being cut down. Meanwhile, journalists investigated where this valuable chopped wood went and who was benefitting. ${ }^{3}$ Lawyers who were part of the 6700 Green Trees Facebook group signed an appeal that called for the urgent suspension of tree cutting due to signs of illegality. They also developed an online handbook to teach students in the movement how to take to the streets in protest. In addition to all of these independent events, a workshop on tree protection was organized by formal 
organizations (People and Nature Reconciliation [PanNature] and the Center for Media in Educating Community [MEC], the latter being under the Vietnam Union of Science and Technology Associations [VUSTA]). However, an unexpected electrical blackout disrupted the workshop. As these events were unfolding and being described on Facebook, online discussions increasingly began to focus on the government's lack of transparency and responsibility. While initial discussions began by demanding to save the trees, they eventually broadened to ask for political transparency.

\section{Collecting Young People's Stories}

The Tree Hug Movement was in essence a movement of young people. Almost one year after the movement had started, seventy-five percent of the members of the movement's most important Facebook presence, the page 6,700 People for 6,700 Green Trees, were young people between eighteen and thirty-four years old (Figure 1). As we will argue, these young protesters demanded rights to the city by asserting their youthful ways of life.

\section{[FIGURE 1 NEAR HERE]}

Vietnamese researchers who were closely involved in the Tree Hug Movement explain how it created an unprecedented "culture of dialogue/expression":

Hanoi probably has never seen such vibrant civil actions as those against the city's tree replacement project. There has never been such willingness to take action and cooperate in a free and voluntary manner from most classes of people. Each person took initiatives in the movement by offering their competence and capacity to protect trees; there was no need for instruction, reassurance or command. (Lê Quang Bình et al. 2015, 18)

The Tree Hug Movement brings to light an important generational rupture in Vietnam. Young Hanoians are not only the first generation born after the initiation of the economic reforms 
since the late 1990s (known as đổi mói); they are also the first to extensively integrate new media and communications technology into their daily lives. In her work on youth activism in the Middle East, Linda Herrera speaks of a "wired generation." She offers the concept of rewiring to analyze how young people's "relationship to political and social systems and their notion of themselves as citizens" are changing with the advent of new technologies (Herrera 2012, 335). In Hanoi, we can speak of a wired generation in a post-reform and communist context that is generating new forms of political engagement. Asef Bayat (2012) describes how cities in Egypt and Iran are "cities-inside-out" because there is an extensive use of the street for domestic chores, work, and leisure in the Middle East. He argues that this has contributed to the formation of the "political street," as the passive networks of "instantaneous communications between atomized individuals are established by tacit recognition of their commonalities and are mediated through real or virtual space" (Bayat 2012, 120). In Hanoi, these networks created by instantaneous communications between atomized individuals exist as well, as they emerge in a comparable blurring between the public and the private (for Hanoi, see Drummond 2000, and Drummond and Lien 2008; for Ho Chi Minh City, see Kim 2015). Street use for cleaning, cooking, eating, or hair dressing is intense, although there is a strong trend for retrieving these activities from the public eye in upper-middle-class areas (see Harms 2009). In what follows, we explore how the blurring of public and private (physical and virtual) space has contributed to the young "political street" in Vietnam.

Drawing upon two years of fieldwork in Hanoi, we explore how young people in the city struggle to create a space for their youthful lifestyles and how this struggle contributed to the emergence of the Tree Hug Movement. In addition to ethnographic observations, we conducted sixty qualitative interviews in Vietnamese with individual youth and eleven group discussions with youth (aged sixteen to twenty-five years) who frequently inhabited three public spaces in 
Hanoi: Lenin Square in the city center, the 34T Plaza in a newly developed residential area, and Hoa Binh Park on the periphery of the city. This initial data was collected in 2013 and 2014. As we were writing up our analysis, the Tree Hug Movement emerged and we went back to our key informants to conduct fifteen additional semi-structured interviews between April-June 2015 and May-June 2016. We spoke to eight young persons who participated in the movement directly, aged between sixteen and twenty-five years. In addition, we met with four informants closely involved in running the movement's various Facebook platforms: Trà (female founder and administrator, thirty-one years old) and Thì (female administrator, thirty-three years old) of the first platform, the page 6,700 People for 6,700 Green Trees; Hà (male founder and administrator, thirty-eight years old) of the group 6700 Green Trees; and Pham (female environmental activist and independent journalist, thirty-eight years old), not an administrator but part of the sixmember core group running the group For a Green Hanoi. Finally, we spoke with two NGO workers and a university lecturer. One of the NGO workers was Hương (female, thirty-four years old), who works for an international NGO managing their Livable Cities program. She was involved in the very first off-line meeting of the Tree Hug Movement and in the earlier Save the Unification Park campaign. The other NGO worker was Giáp. He was a twenty-eight-year-old LGBT rights activist and manager of the local NGO iSee, which participated in organizing the Tree Hug Picnic. The university lecturer was Giang. She was a fifty-four-year-old well-known environmental activist.

Further insights were gained from direct observation by one of the authors who was based in Hanoi throughout this study. With the support of Hiên, a female Vietnamese graduate student who, as we noted earlier, was actively involved in the Tree Hug Movement, this author was able to follow the movement in person, in both physical and virtual spaces. ${ }^{4}$ 
We began this research with the goal of understanding how youth create spaces of action for themselves in Hanoi. In a city characterized by authoritarian governance, a strict age hierarchy, crowded homes, and shrinking urban open spaces, we aimed to better understand how young people find ways to play. While much of the public debate in Hanoi revolves around the dangers of the privatization of public space and the "social evils" that flourish in them, we sought to enter the world of Hanoian youth to better understand what they want, how they manage to get it, and how they speak about their urban lifestyles.

As we began our research, we were immediately struck by the importance of virtual public spaces such as Facebook, and the ways in which the wired generation relies on social media to live "life as art." As previously noted, "life as art" is an expression widely used by youth in Hanoi. We suggest it is the key to understanding this generational rupture and the emergence of new forms of political agency such as the Tree Hug Movement. It refers to a more free-flowing, less hierarchical, and more unpredictable life than what Vietnamese sociocultural values would typically allow for. "Life as art" describes the horizontal, free-spirited atmosphere during the events organized by the movement, and the assertion of a culture of diversity by young participants. To make space for their aspiration of "life as art," their creative activities, and freeflowing ideas, the younger generations in Hanoi mobilized non-confrontational tactics. In an authoritarian country and in a society marked by a strict age hierarchy, this is not surprising. However, this paper argues that there is much to be learned about how these non-confrontational tactics to claim space can evolve into non-confrontational politics. By looking at the lives and actions of Hiên and her friends, we were reminded of how these modes of political engagement are becoming increasingly important in a global urban world.

\section{The Wired Generation and their Political Engagement}


Despite local specificities, being young in Hanoi is in many ways similar to being young in New York, Mexico, or Paris. This generation of urban youth has developed a collective identity through the sharing of images and ideas in physical and digital spaces. Generational sociologists speak of the "global generation" (Edmunds and Turner 2005). They conceptualize generations as a social phenomenon instead of a set of biological characteristics. Inspired by the work of Mannheim (1952), they argue that to be qualified as a generation, a cohort needs to share a distinctive social consciousness. Whether a generation succeeds in developing such consciousness depends, according to Mannheim, on the "tempo of social change" (Mannheim 1952, 309). In times of accelerated social change, such as those brought by contemporary urbanization, youth are less reliant on the older generation's memories (Pilcher 1994, 491). Many scholars have named this global generation solely with reference to new digital platforms and technology (e.g., the E-generation, the Facebook generation). We find the term wired generation developed by Herrera (2012) more inclusive because it refers to "rewiring" as opportunities to interact and connect with others. We also find rewiring particularly useful for the analysis of this generation's political role, because it emphasizes the importance of the "users" themselves and not just the new digital platforms that rewire them. Rewiring can occur differently in varying contexts, although all users might use the same digital platforms. In authoritarian regimes such as in Vietnam, rewiring has created opportunities for young people to learn about different ways of being young, and about youth politics and techniques for bypassing repression through political activism.

The contrast this has produced in Vietnam between this younger generation and the older generation is significant. The younger generation (under thirty-one years old for Vietnam's census purposes) makes up half of the country's population (Worldometers 2015), although 
youthfulness goes beyond biological age. It refers to a set of attitudes and ways of being. Bayat puts it beautifully:

A youth movement is essentially about claiming youthfulness, it embodies the collective challenge whose central goal consists of defending and extending the youth habitus, by which I mean a series of dispositions, ways of being, feeling, and carrying oneself (e.g., a greater tendency for experimentation, adventurism, idealism, autonomy, mobility, and change) that are associated with the sociological fact of "being young." (2010, 118; emphasis in the original)

In Vietnam, the older generation was part of a largely rural society in which peasant and working youth were considered pillars for the construction of a socialist country (Nguyễn Phượng An 2006). The younger generation is now part of an increasingly urban society. Cities expose youth to more diverse lifestyles and more autonomy from their family and state institutions. An urban way of life modifies how people relate to space, time, and affect, and this impacts how they act and interact. This urban logic of action favors the emergence of new political forms (Boudreau 2017). This is particularly striking in non-democratic contexts such as Vietnam because state socialism relies on a modern, rational, and state-centric form of governance that clashes with the networked and affective forms of urban politics.

This younger generation of Vietnamese did not experience the war, the division between the North and South, or their parents' poverty. Instead their concerns are the economic, moral, and social conditions of today's society (Marr and Rosen 1998). The older Vietnamese generation grew up in a time of more constrained state control through the Youth Union and the Ho Chi Minh Young Pioneers. Youth unions still exist today but have lost popularity. Claims of youthfulness are essentially a new urban phenomenon driven by educated young people. The media depicts this new vibrant youth culture as uncritically and irresponsibly embracing the 
global market and its commodities (Schwenkel 2011). This wired generation is further associated in the media with social problems, portrayed as a generation that has forgotten its nation's history, moral values, and cultural identity (Marr and Rosen 1998).

Indeed, the younger urban generation is increasingly adopting individualistic values and the state is no longer central in shaping their life course (Thomas 2002; Nguyễn Phượng An 2006). A generation of young professionals is emerging in Vietnamese cities, representing a new middle class that is not so different from young middle classes elsewhere in the world (King, Nguyen, and Minh 2008, 801). In the largest Vietnamese cities, youth no longer have "career and stability" on the top of their list of priorities; instead they tend to emphasize "happiness and family" (King, Nguyen, and Minh 2008, 802). King, Nguyen, and Minh (2008) conclude their study of middle-class youth in post-reform Vietnam by stating that "those in power in Vietnam will have to make sustained efforts to accommodate [professional middle-class youth] interests, needs and aspirations" $(2008,808)$. Of course, not all youth are middle class, urban, and educated. But this segment of professional middle-class youth is the most visible and vocal in claiming their youthfulness.

That these young Vietnamese belong to the wired generation is clear. They themselves speak of generational differences and exhibit a new collective identity as "youth." They adopt global ideas and practices, although within the limits of local sociopolitical values. By choosing to live their lives as "art" they embrace values such as individuality and autonomy. As a twentytwo-year-old male graduate student in Environmental Engineering explained, “To me, 'living life as art' is living with my passion and doing whatever I want to" (Anh Tuan, interview, 22 June, 2015). Moreover, in the words of a young male photographer we met at the 34T Plaza: "Young people can find enjoyment in practicing parkour or skating. To be at their level, they need to practice a lot and that is how they live with their passion. It is a kind of art" (Việt Anh, interview, 
June 22, 2015). He further explained why he believes he lives his "life as art" and why this is different from other people's lives:

Nowadays, people don’t encourage kids just to study-just simply work and eat without creativity and enjoyment. Enjoyment comes not only after achieving something but also from enjoying the process. For example, a person can go travel after a hardworking period, take pictures, and see themselves in those pictures. It is enjoyment, but to me this is not satisfying. After, they want to earn more money and live for that. My life is much better and I live my life with more freedom and passion. I can bring my camera [with me for] the whole day and take pictures of everyone I meet and come up with ideas until midnight. (Việt Anh, interview, June 22, 2015)

Youth choose to live their "lives as art" in ways in which they can remain faithful to, and thus avoid confrontation with, the sociopolitical Vietnamese environment. Sharbaugh and Nguyen address the fine line between legitimate commentary and "reactionary" content in Vietnamese online and off-line language $(2014,162)$. They conclude that the wired generation, as we call them, is able to communicate online about a wide variety of Vietnamese social and political issues by relying on the tactic of "remixing content" to "discreetly satirize" $(2014,162)$. In other words, the wired generation's search for more autonomy is essentially non-confrontational.

When we immersed ourselves in Hanoian youth culture in public spaces, we observed how the Vietnamese youth used non-confrontational tactics in their use of public space (Boudreau et al. 2015; Geertman et al. 2016). Despite constant expulsion by the police or private management guards, different youth groups returned to public spaces, quietly occupying them in order to normalize their presence in the everyday urban landscape (Figure 2). For instance, a young traceur (practitioner of parkour) at the 34T Plaza explained to us how residents of the 
newly built residential towers surrounding the plaza regularly asked the guards to forbid activities that they — the residents — found too noisy or dangerous for the elderly and for children. The residents themselves installed signs prohibiting parkour or skateboarding, but young people decided to return to the plaza during off-peak hours to avoid trouble. These youth also raised the level of social acceptance for their activities in public spaces by promoting them online (via Facebook and YouTube) and by using positive arguments for these activities, such as the physical and mental health benefits. In both verbal and non-verbal communication in physical public spaces and in their Facebook posts, the youth carefully avoided conflict with each other, other users, and the government. In doing so, they continuously challenged social norms concerning the appropriate uses of public space (Figure 3).

\section{[FIGURE 2 NEAR HERE]}

\section{[FIGURE 3 NEAR HERE]}

Youth leisure activities such as hip-hop dancing in public squares, skateboarding, or parkour may seem barely subversive (and possibly completely apolitical and inconsequential). Nevertheless, such activities quietly and gradually erode existing power structures by encouraging young people to challenge existing social norms about appropriate activities in public space in Vietnam, which are traditionally initiated from above through the Youth Union. In a similarly authoritarian context, Bayat (2010) conceptualizes such practices as a nonmovement that works through the public presence of passive networks of atomized individuals in everyday settings. Through such practices, individuals take part in the "quiet encroachment" of public spaces or streets. We have elsewhere explained how the Hanoi youth non-movement is characterized by a feedback loop between individuals who spontaneously organize with likeminded youth (Geertman et al. 2016). We showed how this evolved as a non-movement because their networks are more free-flowing and flexible than what is commonly understood as an 
organized movement. However, when young Hanoians actively and consciously assert their collective identities as skateboarders or hip-hop dancers or other practitioners of street disciplines in public spaces, they set themselves apart from the more passive forms of resistance characteristic of the non-movements documented by Bayat (2010). In other words, nonmovements can become explicitly political. In what follows, we argue that this is precisely what happened with the Tree Hug Movement in Hanoi: from the public practice of expressive forms of globalized culture ("life as art”), Hanoian youth began to politically mobilize.

\section{The Tree Hug Movement in Physical and Digital Spaces: From Play to Politics}

The cutting of 6,700 trees directly affects the use of public spaces by creating areas with less shade and a less green space. In short, it creates a less friendly and desirable atmosphere. For most participants, opposition to the tree cutting was based on these pragmatic reasons, but they gradually contributed to a more direct political discourse on "rights" and "transparency." How did this shift occur, and how did a large group of young people get involved? In order to understand this, we have to look at the intertwining of physical and digital public spaces.

All of the youth groups we interviewed gathered both in physical public space and on Facebook. These youth groups acted as informal groups centered on an activity (e.g., skateboarding, learning English, football). In Vietnam, youth reproduce how Vietnamese society is organized around structured groups with clear hierarchies. The difference is that the youth groups we interviewed were largely auto-generated. They were not organized from the top-down by state-controlled mass organizations. Of the eleven group discussions that we conducted during this research, only the skateboarders did not have a clear leader. The other ten groups-engaged in lifestyle sports such as hip-hop dancing, parkour, and more conventional sports like soccer or shuttlecock (da cau)—had clear structures, logos, and practice schedules. The group members interacted and organized activities with one another through their interrelated uses of physical 
and digital spaces. The extensive use of Facebook by these youth led them to be informed about the tree cutting. Hiên explained how this worked:

I was really upset that so few youth cared about their rights, but when I began to get more involved [in Facebook discussions on the tree cutting], I met more people like me. Even in my network of friends, there were lots of people who didn't care about the trees and their rights. But when I liked and shared it [the Facebook post with new ideas on human rights and politics related to the tree cutting in Hanoi], there was something new on their page. Then they started to realize that this is right and true. They learned something new, they all liked the page I liked and the effect was doubled and then doubled again, and now more friends in my network care about social issues — or they did care before but they never showed it. It's quite promising. They are following the source of information now [any of the Tree Hug Movement Facebook platforms]. I think it will go further in the future. (Interview, June 26, 2015)

In Vietnam, Facebook is often blocked, especially during politically sensitive times. However, a Facebook blockage can be bypassed using several tricks (changing DNS, using a proxy, etc.). In 2013, the website Tech in Asia wrote that “Today, blocked or not, Vietnam's Internet population is by far the most aggressive Facebook population in the region" (Tech in Asia 2013). The government implemented a series of regulations (Decree No. 2) ranging from 2011 sanctions for journalists who violate vaguely defined provisions, to a 2013 clause (Decree No. 72) stipulating that blogs and social media sites can only be used to share "personal information" and not news articles. Despite facing a storm of protest from Vietnam's Internet users and international technology companies such as Google and Facebook, as well as several human rights organizations who accused the government of undermining free speech (Global Voices 2014), the 
restrictions continued into 2014 until new requirements for social media were issued in Circular No. 09 that further restricted the management, provision, and use of information on websites and social networking services (Ministry of Information and Communication [Vietnam] 2014). The stipulations in this circular ranged from requiring that the person responsible for the content of a social media service or website be the head of an organization or enterprise or the deputy thereof who has a university or higher degree, to requiring the appointment of a technical person who is suitably skilled in information safety and security (In-House Community 2014). Nevertheless, today, youth continue to use social media extensively. More young people are also following politically-oriented Facebook groups as a consequence of their involvement in the Tree Hug Movement (Lê Quang Bình et al. 2015).

Facebook is a platform that also allowed youth who were neither confident nor comfortable enough (yet) to actively participate in online discussions, or take to the streets in protest, to participate in a passive way in the Tree Hug Movement. Lý is a high school student. She expressed reservations and fear about direct political engagement:

I still have to care about myself, my future and family. Something bad might happen if I join the protest. . . . I joined some Facebook groups about the [Tree Hug] Movement and just watched silently and signed onto the petition. (Interview, June 24, 2015)

Lý further justified her "silence” by stating: "I don't think that I should join their discussion since I don't have enough information now" (interview, June 24, 2015). Yet, she also articulated an explicitly political argument:

I was not born here but have been living in Hanoi for ten years and I know that green trees are the most beautiful thing in Hanoi. They [HPC] cut them down with complete impunity then plant new trees, ${ }^{5}$ with so many lies. I can see a lot of 
problems here and we need to make it [the tree cutting and replanting process] more transparent. (Interview, June 24, 2015)

This passive digital network, involving mutual recognition and non-verbal interactions (agreeing with the information posted online, signing the petition, etc.), is articulated by Bayat's notion of the "political street." Given the entwinement of physical and virtual public spaces for Hanoian youth, it is reasonable to see Facebook as a "political street." The transition from a nonmovement of youth living their "lives as art" in physical and virtual spaces to the Tree Hug Movement - that is, the transition from playing in public space to being involved in a political movement—worked using the same tactics these youth applied to opening space for their activities in Hanoi's public spaces: quiet encroachment through occupation, positive arguments, and avoidance of confrontation and conflict. The example of parkour in the 34T Plaza described above illustrates well the tactic of quiet encroachment. Convinced of their legitimate right to use the space, Tuấn, a twenty-three-year-old male traceur, explained: "we just come here shamelessly" (interview, November 17, 2013). As previously noted, skateboarders and traceurs used positive arguments to convince their parents to let them engage in these new activities. For instance, they argued that team members often studied together for exams, and helped each other find jobs and stay away from using drugs. They used their preferred practice space (the stairs in front of the entrance of the $34 \mathrm{~T}$ building, which is centrally located within the $34 \mathrm{~T}$ Plaza) during work hours, when most residents are absent. When the plaza became crowded, they quietly retreated to the less intensely used edges of the plaza. "They [security guards] talk, we politely listen, then after a while when they leave, we come back and continue to practice" (Tuấn, interview, November 16, 2013).

As mentioned previously, many of the young people with whom we spoke in Hanoi's public spaces told us that they desired to live their "lives as art." They perceived this as a free- 
flowing lifestyle for which public spaces were considered the perfect locations. It is in physical and virtual public spaces that youth can engage in activities that are often collective and transgressive in nature. Youth use the city's squares, plazas, parks, and streets for study groups, music groups, circus groups, meeting a lover, or engaging in lifestyle sports (referred to as $n g h \hat{e}$ thuật đương phố [street-arts]) such as skateboarding, hip-hop dancing, parkour, etc. When we asked Tuấn why he decided to be a traceur, he immediately responded: "If you understand the philosophy of this activity, you will see that it frees your spirit" (interview, November 16, 2013). Phong, who is twenty-two years old, actively participated in the Tree Hug Movement. When we met him at Lenin Square, he told us how choosing to live "life as art" also means living in the "here and now" (interview, June 15, 2015). Information is absorbed instantly; decision-making does not require too much thinking. Living life as art is more intuitive and individual than what the Youth Union would allow for. It is based on immediate responses and free-flowing actions.

"Life as art" is an urban youth lifestyle echoing a long bohemian tradition in the city. In revolutionary Vietnam, urban bohemian artists developed a critical relationship to socialist realism, questioning the "objective" truth propagated by socialist artistic norms (Ninh 2002). These bohemian reform artists have developed critical artwork they increasingly showcase in urban public spaces (Geertman 2016). In essence, it was the artistic aspiration to break free from sociopolitical norms that resonated with the Vietnamese young people we interviewed. In their explanation of why they aspired to live their "lives as art," youth regularly emphasized words such as tụ do (freedom) and thoải mai (ease). Some of them also talked about living a "bùi bấm lifestyle," a colloquial expression that connotes a nonchalant and non-conforming, bohemian way of life.

In the context of Vietnam, claiming such artful youthfulness can be interpreted as an attempt to break free from the cultural and political constraints that channel youth into 
conformity and encourage them to be constantly competing against each other in order to move up the social ladder. As a reaction to this dominant moral and social order, approaching "life as art" is understood here as living a non-competitive, self-motivated, and self-directed existence that may or may not fit into the existing models promoted by the state or by their families.

This aspiration to live "life as art" is of course not limited to youth; many others in society similarly aspire to live a more free-flowing life and to be part of a less constrained sociopolitical environment. Reform artists are just one example. Nonetheless, it is the younger generation that is most visibly choosing to live "life as art." They express this lifestyle in public by (visually) presenting their activities in physical public spaces, and online they publicly discuss their passions and activities. As such, they actively promote their aspirations for this less constrained lifestyle to others. It was in this context that the Tree Hug Movement emerged.

\section{Quiet Encroachment and Informal Forms of Political Engagement}

It all began the day after journalist Trần Đăng Tuấn posted, on his Facebook page, an open letter to the chairman of HPC. The letter asked for a delay in cutting the trees in order to investigate the validity of the project. In response to massive public support following the open letter, the Propaganda Department organized a press conference two days later (March 18, 2015). However, the Department's representatives at the press conference did not provide answers to most of the questions raised by journalists and it soon became clear that the press conference was used as an attempt to tame critical questions, rather than provide answers. This led to public outcry when, at the press conference, the Deputy Head of the Department was asked to respond to the open letter:

Deputy HeAd, PRopaganda DePaRTMEnT. Trần Đăng Tuấn is an ordinary citizen. The city has already approved a master plan with many public offices involved. Even if he does not agree, he is just one among many ordinary citizens. What if there are many other people who agree? 
REPORTER. You mean, the citizenry has not been consulted?

Deputy Head, Propaganda Department. Do you mean we have to consult the people on everything? It's just a project about trees. I am asking you: If we have to consult the people about everything, why do we elect the government? (Vietnam Right Now 2015)

This conversation was widely quoted in both print and online media. Instead of calming down the public, it led to more claims for government transparency and accountability.

When living their "lives as art," members of this younger generation begin to speak their minds. They do not simply "talk" about politics; they also learn about what it means to be politically engaged. Hiên insisted that her own involvement in the Tree Hug Movement was the "practice" she needed to teach her friends about being political engaged. She explained how this was different from previous generations:

It's not only about protecting the city. It's also about protecting our rights as residents. When we take part in this movement it's like we are asserting our rights. We have the right to know [about governmental decisions and implementation of changes in the city] and we need to know. Our parents didn't know about this in the past, and my mother still fears that I might get into trouble. I might, but if I don't do this, the future generation will not have trees anymore and they will not know that they have the right to raise their voice. In the beginning, it was only about trees, but by now it's not just about the trees anymore, it's about political rights. It isn't just me and a couple of others. I think a lot of my friends think this way. We have better information now, and we can read from abroad [information published outside of Vietnam], so that is how we think about this. (Interview, June 26, 2015) 
Phượng, a twenty-one-year-old female student, further explained how creating spaces for common reflection contributes to affirming her values by making them more visible. "Two or three years ago," Phượng went on,

I only cared about studying, but recently, I started to realize that the government is hiding too many things from us. Like the lack of information about the trees being cut down. After this movement, more young people like me will know about their political responsibility. (Interview, June 24, 2015)

Phượng and Hiên moved from demands for the protection of trees needed for their daily use when living their "lives as art" in virtual space and the public spaces of the city, to demands for government transparency.

\section{Affective Arguments}

When Trà created the Facebook page 6,700 People for 6,700 Green Trees, she was not the only one creating such a Facebook page. A journalist had already started a page concerning the removal of the trees shortly before Trà created her page, but only Trà's page went viral. Thì, a human rights advocate and the second person behind the 6,700 People for 6,700 Green Trees page, explained why she decided to support Trà:

Her page was very strong and natural. She was an ordinary young woman with a softtoned, inspiring voice that went viral very quickly, so I started to invite all my friends to check out that page. I invited her to join a meeting the next day with about thirty of my friends. These were all people I know, except Trà, the owner of the page. She was new. (Interview, May 26, 2016)

Thì’s explanation emphasizes affective non-confrontational political forms: "her page was ... natural," and written in a "soft-toned, inspiring voice." This form of political action, as we have argued elsewhere, is becoming one of the most important characteristics in 
contemporary urban societies (Boudreau 2017). Instead of putting forward a rational argument based on "facts" to convince opponents, Trà appealed to affective relations, and she did that online as much as she did during the face-to-face meeting with Thì's friends.

Thì's friends were young human rights advocates, environmental activists (including architects), journalists, lawyers, state officials, and NGO workers. Hương and Giàp (respectively working for a foreign and a local NGO) informed us that everyone at that meeting joined in their personal capacities, as a group of friends who were concerned about the environment. After that meeting, Thì and her friend Long (a twenty-three-year-old male) joined Trà to administer the page. Thì explained: "Trà was the perfect choice: she is a young housewife. No one knew who she was and being known as a housewife kept me low profile" (interview, May 26, 2016). The Facebook page provided a safe way for people to engage with an issue that might otherwise be unsafe to engage with. Trà confirmed: "We never received questions [from] the authorities" (interview, May 31, 2016).

Trà's voice not only resonated strongly with young people; it also resonated in particular with women (as indicated in Figure 1, sixty-one percent of the total group is female, with seventy-nine percent of these aged between eighteen to thirty-five years). This affected the development of her network. For example, Trà noted how some people (especially older men), would laugh at her and call her group "Gái Tình" which can be translated as "girly” or “feminine" (interview, May 31, 2016). Many young women were attracted to her page as Trà represented many of their struggles. "We Vietnamese women need to be good cooks, caring wives, and we should have kids to be perceived as "wholesome," Trà told us emotionally in an interview (interview, May 31, 2016). Nonetheless, Trà publicly spoke about her rights, and showed she cared about public issues. Instead of opposition, this was how she attracted public sympathy. "Because she did it in a soft way, with a female voice," Thì concluded (interview, 
May 26, 2016). It was this positive tone that resonated with many youth and not only women. Trung, a young male student, echoed this focus on positive and constructive change: "Youths' thoughts and actions will make society more open, freer from its constraints, preconceptions, and even fears. A negative issue can become positive through the gaze of young people" (interview, June 20, 2015).

Around the city, the network initiated several different events where they employed affective arguments to promote the preservation of trees. A Peaceful Walk was organized on March 19, 2015, one day after the press conference that had led to the public outcry. The first event that set that tone was the Tree Hug Picnic (Figure 4). It was organized only four days after the Peaceful Walk, on March 22, 2015. The event was announced with an online invitation to join a Sunday picnic around one of the central lakes, Thiền Quang (next to Unification Park, saved a decade earlier), to celebrate the trees in Hanoi. Giàp informed us that he had created the event from his location in Ho Chi Minh City, after which Thì had shared the event details to the Facebook page 6,700 People for 6,700 Green Trees. During the picnic, a diverse group of young families with kids, a large group of students, the (growing) LGBT community, and artists gathered together and hugged trees, hugged each other, sang songs, and made cut-out paper trees that little children and many of the female students wore. It was a warm, cheerful atmosphere. Youth wore green and pink t-shirts expressing their love for trees. Affective flows were tangible. Only at the moment that the police surrounded the crowd did a wave of tension appear. However, people didn't oppose the police directly. Instead they continued to express happiness with strong positive connections between people and "nature." They worked together with each other and with the trees, hand in "branches," so to speak. We are referring here to what Connolly (2011) would call the trees' proto-agency, their affective vibrations contributing to easing tension and maintaining a joyful, rather than conflictual, atmosphere. This is how the picnic participants 
confronted both the cutting of the trees and police intimidation. "We had no intention to be antistate [phản động] in this event, or any other event," recalled Thì (interview, May 26, 2015).

\section{[FIGURE 4 NEAR HERE]}

The Tree Hug Picnic and the five further Peaceful Walks (Figure 5) that followed during March and April 2015 were not initially perceived as political by many youth, who consequently did not feel that they were in danger. Moreover, it took time for the government to realize these events could destabilize governance. The government only began to make arrests after the sixth Peaceful Walk (April 26, 2015), after two months of mobilization. This exceptional tolerance (other recent Facebook-driven protests had been suppressed much quicker) can be explained by the form and modalities of the walks. Instead of loud and confrontational events that would resemble street protests, the Peaceful Walks had a mostly a positive tone in which a crowd celebrated the trees. Hiên recalled:

It's pretty good that some young people are very active and they have creative ideas like dressing up like a tree. We had a picnic near the lake. Then we sang, danced, and we hugged each other, and we had the idea of hugging trees. These ideas came from young people. They are active. (Interview, June 22, 2015)

The values of a large majority of the movement, the young people, were close to the idea of living "life as art." As trees were being hugged, this wired generation was advocating for peace, equality, diversity, and transparency.

[FIGURE 5 NEAR HERE]

\section{Conflict Avoidance}

In April 2015, the government began to repress the protesters taking part in the Cycling for Trees and in the Peaceful Walks events. Protesters were beaten and arrested. Giang explained how university teachers at state universities were asked to request that their students to withdraw from 
the movement (interview, 29 May, 2016). Students also received visits from local government officials at their homes. Their participation in the movement put their families at risk as well. Many of the students started to withdraw from the movement by not attending the Peaceful Walks. "Now, we are afraid to join any protest because Vietnam doesn't allow citizens to protest and we can be arrested. I still want to go abroad to study so it would be easier for me to fight in the future," said Phượng (interview, June 24, 2015). Hà, initiator of the 6700 Green Trees Facebook group, also excluded many of these youth from the Facebook group for their own protection. He explained:

I worked with police officers and told them that these students were no longer group administrators [of the 6700 Green Trees Facebook group]. If there is a problem, the police should come to see me - and only me. Later, the police officers stopped going to the students' houses. I didn't want the students to be affected, though, so I took them off the list of administrators. I don't want them to have any trouble with the government or police. (Interview, June 26, 2015) Phượng, Hiên, and Trung were displeased by this exclusion, which they saw as government infiltration. Hà is also the leader of the online architecture platform Ashui, registered under the Vietnam Urban Planning Association. While excluding members from administering the Facebook group who were at risk of arrest was justified in terms of care and safety, it also served to safeguard the position of Ashui as a legitimate government interlocutor for future urban projects. Explicit anti-government confrontation was quickly pushed to the margins, making space for non-confrontational tactics. The excluded administrators and participating activists responded by creating the third Facebook group, For a Green Hanoi, to continue their activities. Many activists in this third network were considered by the state as reactionary/anti-revolutionary (phản động), and thus confrontational. 
Trà's network also used exclusion as a tactic to avoid conflict. Both Trà and Thì explained how they removed posts that they perceived as too confrontational and also how they excluded individuals — among them, Giang and Pham — who were considered by the state to be reactionary/anti-revolutionary activists from events that the network initiated. Pham explained:

When Trà and her network organized the picnic, we received a friendly message from that group, [asking us] if we could stay away from that event, to make sure the event would not be disturbed by the police [which could involve violence or arrests]. So we didn't join them. Instead, we followed that event closely on Facebook. (Interview, June 2, 2016)

All three networks aimed to prevent conflicts among their members in order to ensure a strong collective voice for each network. They did this by organizing smaller core groups in addition to the public Facebook platforms. These core groups frequently met off-line to strategize. Thì revealed to us, for example, how their group also had an additional "secret Facebook group" of about 100 people. From that (hidden) forum for discussion, "Trà would choose what she would post on the public Facebook page" (interview, May 26, 2016). In this context, exclusion was a tactic of conflict avoidance, not an emotionally-charged relational disagreement. However, it nonetheless provoked harsh feelings or disagreement, as expressed by Phượng, Hiên, and Trung.

\section{Conclusion: The Increasing Importance of Non-confrontational Politics in an Urban World}

On July 21, 2015, city authorities finally announced their own conclusion about the tree removal project: the state confirmed the project was legal and procedural, but recognized some mistakes had been made in its implementation. Lower-level governmental staff were suspended, while other high-ranking officials were asked to self-criticize. Although most citizen groups involved in this movement are still unsatisfied with this result, many trees have been saved. The citizens had voiced their views, and succeeded in starting a dialogue on public participation in government 
projects in Hanoi. The networks of young people participating in the Tree Hug Movement contributed considerably to the development of an independent civil society in Vietnam. They followed and supported the tree-cutting protests that took place in Ho Chi Minh City in 2016. Hiên and her friends also participated in the nationwide protests related to massive sea fish deaths in 2016 (during these protests, the administrators of For a Green Hanoi strategically created a new Facebook group, Green Trees, to keep themselves low profile and keep pro-government intruders out of the group).

The Tree Hug Movement demonstrates how digital communications can allow for the emergence of a self-directed network of ordinary (young) people who can trigger significant political change through non-confrontational tactics (Madianou and Miller 2013). But we wish to suggest that there is more to this than a technological revolution.

This paper sought to illustrate how living "life as art" for Hiên and her friends fed into their involvement in youthful forms of urban politics. Pre-digital generations in both democratic and non-democratic countries grew up in a much less connected and a significantly less urban world in which the idea of the state as the main interlocutor was dominant. In the modern world of nation-states, political action unfolded on clearly defined territory (the sovereign nation state). The political process tended to favor linear and organized action based on clear leadership with specific professional expertise. Moreover, the temporality of political change was conceived as a historical march towards progress. The stability of the space of action and of linear time facilitated pretention to scientific rationality as the motor of legitimate action. People calculated, planned, and acted because they thought they could master the parameters of the issue at stake. In the contemporary world of cities, people still act strategically and hope for a better future. But other forms of political action are increasingly visible: acting spontaneously (that is, without a planned strategy), developing tactics as agents respond to immediate situations, or 
acting out of passion or rage more than ideology. This brings our attention to other rationalities of action based on creativity, unpredictability, sensorial stimulation, intuition, emotion, and loss of control. These rationalities of action lead to a more diffuse form of political action such as the Tree Hug Movement. The motor of this process of political informalization was not so much antagonism and contention as impulsion - that is, the intensification of multiple encounters and experiments that are characteristic of urban ways of life.

The role of Facebook for the wired generation in Hanoi is a vivid illustration of this urban logic of action. Instead of favoring rationally planned actions by experts, the political process is led by ordinary citizens, and marked by creativity, unpredictability, celebration, and enjoyment, as well as intuition and emotions. In their work on online remixing and meme culture, Sharbaugh and Nguyen suggest that

the broad circulation of embedded ideas via new image-based social media platforms in Vietnam is cultivating a level of civic engagement that is unprecedented for a nation in which traditional civil society has long been proscribed. This infusion of powerful new conversational capabilities for a growing population —one that is increasingly comfortable with dialogue and debate-portends a fundamental shift in the relationship between individuals and the state as Vietnam moves into the twenty-first century. $(2014,162)$

If these transformations are particularly striking in Vietnam, they are also present in many other cities (see for instance Juris 2012; Horton and Kraftl 2009). If new technologies open new spaces to develop "conversational capabilities," what we saw as we entered youth worlds in Hanoi was a strong desire for what we could call interpersonal citizenship. Like the housewives described by Linda McGirr (2001) in her exploration of Reagan's rise to power in the United States through a loose network of "kitchen table conversations," living "life as art" in Vietnam is 
a cultural transformation based on affective interpersonal discussions in both physical and online public spaces.

In Hanoi, young people went from play to politics, from living their "lives as art" to the Tree Hug Movement, for three reasons. First, their regular use of Facebook exposed them to information about the massive tree-cutting process. Secondly, because the tree cutting affected their play by reducing space with shade and greenery in urban parks, it affected their feelings of well-being and their connection to the parks. And finally, it was easy for them to transfer the nonconfrontational tactics they had developed to secure space for themselves in public parks onto the political scene: asserting their presence, avoiding conflicts, and relying on creative and affective arguments.

Our increasingly urban world composed of a rapidly rising youth population calls for a profound rethinking of how we act socially and politically and how we engage with our surroundings. Our incursions into the wired generation of Hanoi and their urban worlds provide evidence that there is much to be learned from young people's use of non-confrontational politics and their contribution to meaningful change. If in other settings these new political forms were sustained for much longer periods, occupying space (as in the Occupy and the Indignados movements) or even overturning governments, non-confrontational and playful politics cannot have such overtly visible consequences in more authoritarian regimes. However, as Bayat (2010) showed for Teheran, and as the growing number of studies on the strengthening of civil society in Vietnam attest, these small gestures and short moments of political action have a long-term, cumulative effect. The fact that they are sustained by youth may also point, in the longer run, to transformations brought about by a generational rupture with the current regime.

\section{Notes}

\section{Acknowledgements}


Research for this paper was conducted as part of the research project Youth-Friendly Public Spaces in a Context of Rapid Urbanization, funded for the period 2013-2015 by the Social Sciences and Humanities Research Council of Canada (SSHRC) for a collaborative project between the Institut national de la recherche scientifique (INRS, Canada), the Institute of Sociology of the Vietnamese Academy of Social Sciences (IoS-VASS, Vietnam), and HealthBridge (Vietnam and Canada). The data collected and research results (including a research report and videos with youth) are published at http://www.hanoiyouthpublicspace.com/. 
${ }^{1}$ The quotes from the interviews with Hiên, Trà, Thì, Giàp, Giang, and Pham are in the original English. We have translated all other quotes from interviews conducted as part of our research project from the original Vietnamese into English.

${ }^{2}$ This population total comprises the combined number of Facebook page "likes" and Facebook group members for these platforms, as calculated on May 22, 2015. The number of likes for the Facebook page 6700 people for 6700 trees was double the combined number of members of the other two Facebook groups, the 6700 Green Trees and For A Green Hanoi, (respectively, approximately 60,000 likes, and 20,000 and 10,000 online members). The Facebook page 6,700 People for 6,700 Green Trees is located at [https://www.facebook.com/manfortree/]; the Facebook group 6700 Green Trees is located at [https://www.facebook.com/6700cayxanh/]; the Facebook group For A Green Hanoi is located at [https://www.facebook.com/groups/vimothanoixanh/].

${ }^{3}$ Journalists discovered that wood had disappeared from the disassembling centers around Hanoi. In particular, wood from the xà cù̀ tree (African mahogany or Khaya senegalensis) from Nguyen Chi Thanh Street was not present at any of the dissembling points. Although the journalists assumed that the companies involved in the project were benefitting from illegally selling the wood, the government claimed there was no such thing going on (Dân Việt 2015). However, even if the wood was not (illegally) sold, the companies involved nonetheless benefitted, as they were allowed to sell the wood at auctions and received high prices for the valuable wood (Đầu Tu 2015).

${ }^{4}$ With the exception of the founders of the Facebook page 6,700 People for 6,700 Green Trees and the Facebook group 6700 Green Trees, who are publicly known, all interviewees' names are fictional. 
${ }^{5}$ In March 2015, HPC had announced that old trees would be replaced with Manglietia Dandyi trees, with funding from the Police of Hanoi and the Vietnam Prosperity Bank. In response, discussion broke out in off-line and online media (including Facebook), arguing these trees would grow too slowly, did not provide shade, and were too costly (An Ninh Thủ Đô, 2015). 


\section{References}

Aljazeera. 2016. "Vietnam Police Break Up Protest over Fish Deaths.” Aljazeera, May 9, 2016. http://www.aljazeera.com/news/2016/05/vietnam-protest-fish-deaths160509041334507.html.

An Ninh Thủ Đô. 2015. “Thống nhất trồng cây vàng tâm trên đường Nguyễn Chí Thanh [Unification of the golden hearth at Nguyễn Chí Thanh Street].” An Ninh Thủ Đô, March 3, 2015. http://anninhthudo.vn/thoi-su/thong-nhat-trong-cay-vang-tam-tren-duongnguyen-chi-thanh/599301.antd.

Bayat, Asef. 2010. Life as Politics: How Ordinary People Change the Middle East. Stanford: Stanford University Press.

Bayat, Asef. 2012. "Politics in the City-Inside-Out." City \& Society 24 (2): 110-28.

BBC. 2011. "South China Sea: Vietnamese Hold Anti-Chinese Protest.” BBC News, July 5, 2011. http://www.bbc.com/news/world-asia-pacific-13661779.

BBC. 2012. "Vietnam Breaks Up Anti-China Protests.” BBC News, December 9, 2012. http://www.bbc.com/news/world-asia-20656533.

BBC. 2014. "Vietnam Anti-China Protest: Factories Burnt.” BBC News, May 14, 2014. http://www.bbc.com/news/world-asia-27403851.

BBC. 2016. "Vietnam Protest Over Mystery Fish Deaths.” BBC News, May 1, 2016. http://www.bbc.com/news/world-asia-36181575.

Boudreau, Julie-Anne. 2017. Global Urban Politics: Informalization of the State. Cambridge, UK: Polity Press.

Boudreau, Julie-Anne, Laurence Charton, Stephanie Geertman, Danielle Labbé, Pham Thi Thanh Hien, and Dang Nguyen Anh. 2015. Youth-friendly Public Spaces in Hanoi. Research Report. 174 pages. http://www.hanoiyouthpublicspace.com/wp- 
content/uploads/2015/06/FINAL-research-report-small.pdf.

Bùi Hai Thiêm. 2015. "Deconstructing the 'Socialist' Rule of Law in Vietnam: The Changing Discourse on Human Rights in Vietnam's Constitutional Reform Process." Contemporary Southeast Asia: A Journal of International and Strategic Affairs 36 (1): 77-100.

Connolly, William E. 2011. A World of Becoming. Durham, NC: Duke University Press.

Dân Việt. 2015. "Vụ 6700 cây xanh: 'Không có chuyện bán gỗ ra ngoài’ [Department of 6700 trees: 'There is no sale of wood']." Dân Việt, March 24, 2015. http://danviet.vn/tintuc/vu-6700-cay-xanh-khong-co-chuyen-ban-go-ra-ngoai-561479.html.

Đầu Tu. 2015. "Hà Nội: Đấu giá $145 \mathrm{~m} 3$ gỗ cây xanh bị chặt hạ [Hanoi: Auctions of $145 \mathrm{~m}^{3}$ of felled timber]." Đầu Tu, July 27, 2015. http://baodautu.vn/ha-noi-dau-gia-145m3-go-cayxanh-bi-chat-ha-d30256.html.

Drummond, Lisa. 2000. "Street Scenes: Practices of Public and Private Space in Urban Vietnam." Urban Studies 37 (12): 2377-91.

Drummond, Lisa, and Nguyen Thi Lien. 2008. "Uses and Understanding of Public Space Among Young People in Hanoi, Vietnam." In The Politics of Civic Space in Asia: Building Urban Communities, edited by Amrita Daniere and Mike Douglass, 175-96. London: Routledge.

Edmunds, June, and Bryan S. Turner. 2005. "Global Generations: Social Change in the Twentieth Century." The British Journal of Sociology 56 (4): 559-77.

Geertman, Stephanie. 2007. The Self-Organizing City in Vietnam; Processes of Change and Transformation in Housing in Hanoi. Eindhoven, the Netherlands: Bouwstenen Publicatieburo.

Geertman, Stephanie. 2016. "Tactical Urbanism: The Impact of Art Going Public in Hanoi." Paper presented at the 5th International Conference on Vietnamese Studies, Hanoi Vietnam, December 15-18, 2016. 
Geertman, Stephanie, Danielle Labbé, Julie-Anne Boudreau, and Olivier Jacques. 2016. "YouthDriven Tactics of Public Space Appropriation in Hanoi: The Case of Skateboarding and Parkour.” Pacific Affairs 89 (3): 591-611.

Global Voices. 2014. “Corporate Critics Say Vietnam’s New Tech Regulations Are Bad for Business.” Advox, November 3, 2014. https://advox.globalvoices.org/2014/11/04/corporate-critics-say-vietnams-new-techregulations-are-bad-for-business/.

Guardian. 2016. "Vietnam Removes Protesters Gathered for Anti-China Rally in Hanoi." Guardian, July 17, 2016. https://www.theguardian.com/world/2016/jul/17/vietnamremoves-protesters-gathered-for-anti-china-rally-in-hanoi.

Harms, Erik. 2009. “Vietnam's Civilizing Process and the Retreat from the Street: A Turtle's Eye View from Ho Chi Minh City.” City \& Society 21 (2):182-206.

Herrera, Linda. 2012. "Youth and Citizenship in the Digital Age: A View from Egypt.” Harvard Educational Review 82 (3): 333-52.

Horton, John, and Peter Kraftl. 2009. “Small Acts, Kind Words and 'Not Too Much Fuss': Implicit Activisms.” Emotion, Space and Society 2: 14-23.

In-House Community. 2014. "New Procedural Rules for Setting Up a General Information Website and Social Network.” In-House Community, October 14, 2014. http://www.inhousecommunity.com/article/new-procedural-rules-for-setting-up-ageneral-information-website-and-social-network/.

Juris, Jeffrey S. 2012. "Reflections on \#Occupy Everywhere: Social Media, Public Space, and Emerging Logics of Aggregation.” American Ethnologist 39 (2): 259-79.

Kerkvliet, Benedict. 2015. "Regime Critics: Democratization Advocates in Vietnam, 1990s2014." Critical Asian Studies 47 (3): 359-87. 
Kim, Annette. 2015. Sidewalk City: Remapping Public Space in Ho Chi Minh City. Chicago: University of Chicago.

King, Victor T., Nguyễn Phượng An, and Nguyễn Hữu Minh. 2008. "Professional Middle Class Youth in Post-Reform Vietnam: Identity, Continuity and Change." Modern Asian Studies 42 (4): 783-813.

Kürfurst, Sandra. 2012. Redefining Public Space in Hanoi: Places, Practices and Meaning. Zurich: LIT Verlag Münster.

Lê Quang Bình, Đoàn Thị Hà, Nguyễn Thị Thu, and Mai Thanh Tú. 2015. Report on Movements to Protect \# 6700 Trees in Hanoi. Hanoi: Hong Duc Publisher.

Madianou, Mirca, and Miller, Daniel. 2013. "Polymedia: Towards a New Theory of Digital Media in Interpersonal Communication.” International Journal of Cultural Studies 16 (2): $169-87$.

Mannheim, Karl. 1952. Essays on the Sociology of Knowledge. London: RKP.

Marr, David, and Stanley Rosen. 1998. "Chinese and Vietnamese Youth in the 1990s." The China Journal 40: 145-72.

McGirr, Lisa. 2001. Suburban Warriors: The Origins of the New American Right. Princeton, NJ: Princeton University Press.

Ministry of Information and Communication (Vietnam). 2014. Circular No. 09/2014/TT-BTTTT Dated August 19, 2014, on Providing Guidance on Management, Provision, and Use of Information on Websites and Social Networking Websites. http://hethongphapluatvietnam.com/circular-no-09-2014-tt-btttt-dated-august-19-2014-onproviding-guidance-on-management-provision-and-use-of-information-on-websites-andsocial-networking-websites.html. 
Nguyễn Phượng An. 2006. "State-Society Relations in Contemporary Vietnam: An Examination of the Arena of Youth." Asia Pacific Viewpoint 47 (3): 327-41.

Ninh, Kim N. B. 2002. A World Transformed: The Politics of Culture in Revolutionary Vietnam, 1945-1965. Ann Arbor: University of Michigan Press.

Parenteau, Rene, and Nguyen Quoc Thong. 2010. "The Role of Civil Society in Urban Environmental Management.” In The Vietnamese City in Transition, edited by Frank Patrick Gubry, Franck Castiglioni, Jean-Michel Cusset, Nguyễn Thị Thiềng and Phạm Thuý Hương, 167-210. Singapore: Institute of Southeast Asian Studies.

Pilcher, Jane. 1994. “Mannheim's Sociology of Generations: An Undervalued Legacy.” British Journal of Sociology 45 (3), 481-95.

Radio Free Asia. 2011. “Anti-China Protests in Vietnam.” Radio Free Asia, June 5, 2011. http://www.rfa.org/english/news/vietnam/protests-06052011165059.html.

Reuters. 2011. "Hundreds Protest in Vietnam against China over Sea Row.” Reuters, June 5, 2011. http://in.reuters.com/article/idINIndia-57504920110605.

Reuters. 2016. "Rare Rallies in Vietnam over Mysterious Mass Fish Deaths.” Reuters, May 1, 2016. https://www.reuters.com/article/us-vietnam-formosa-plastics-environment/rarerallies-in-vietnam-over-mysterious-mass-fish-deaths-idUSKCNOXSOU6.

Reuters. 2017. "Vietnam Police Halt Anti-China Protest over Islands.” Reuters, January 19, 2017. https://www.reuters.com/article/us-vietnam-protest/vietnam-police-halt-anti-chinaprotest-over-islands-idUSKBN15312C.

Schwenkel, Christina. 2011. "Youth Culture and Fading Memories of War in Hanoi, Vietnam." In Everyday Life in Southeast Asia, edited by Kathleen M. Adams and Kathleen Gillogly, 127-36. Bloomington: Indiana University Press. 
Schwenkel, Christina. 2012. "Civilizing the City: Socialist Ruins and Renewal in Central Vietnam.” Positions 20 (2): 437-70.

Sharbaugh, Patrick, and Dang Nguyen. 2014. "Make Lulz, Not War: How Online Remix and Meme Culture are Empowering Civic Engagement in the Socialist Republic of Vietnam.” Asiascape: Digital Asia 1 (3): 133-68.

Söderström, Ola, and Stephanie Geertman. 2013. "Loose Threads: The Translocal Making of Public Space Policy in Hanoi.” Singapore Journal of Tropical Geography 34 (2): 244-60. Tech in Asia. 2013. "Vietnam's Facebook Penetration Hits over 70\%, Adding 14 Million Users in One Year.” Tech in Asia, September 25, 2013. https://www.techinasia.com/vietnamsfacebook-penetration-hits-70-adding-14-million-users-year/.

The Asia Foundation. 2009. The Mechanism to Settle Administrative Complaints in Vietnam: Challenges and Solutions. Summary Report, August 2009. Hanoi: The Asian Foundation. https://www.asiafoundation.org/resources/pdfs/VNAdminComplaintSettleReportEnglish. pdf.

Thomas, Mandy. 2001. "Public-Spaces/Public Disgraces: Crowds and the State in Contemporary Vietnam.” Sojourn 16 (2): 306-30.

Thomas, Mandy. 2002. “Out of Control: Emergent Cultural Landscape and Political Change in Urban Vietnam.” Urban Studies 39 (9): 1611-24.

Trần Hữu Phúc Tiến. 2002. "Vietnamese Media in Transition.” In Media Fortunes, Changing Times, edited by Russell Heng, 231-48. Singapore: Institute of Southeast Asian Studies. Tuổi Trẻ. 2015. "Hà Nội tiếp tục chặt hạ cây xanh nguy hiểm [Hanoi continues cutting down dangerous trees]." Tuổi Trẻ, April 9, 2015. https://tuoitre.vn/ha-noi-tiep-tuc-chat-ha-cayxanh-nguy-hiem-731840.htm. 
Vietnam Right Now. 2015. "Timeline of the Tree-Felling Project and Tree-Protecting Campaign in Hanoi." Vietnam Right Now, April 28, 2015. http://vietnamrightnow.com/2015/04/timeline-of-the-tree-felling-project-in-hanoi/. Vũ Quốc Cường, Nguyễn Trung Dũng, Nguyễn Hữu Hào, Trần Hoàng Khôi, Triệu Hồng Minh, Lưu Văn Minh, Trần Quảng Nam, Nguyễn Thành Nhân, Đinh Thị Phương Thảo, and Trịnh Anh Tuấn. 2016. From Facebook Down to the Street. Translated by Trần Hà Linh, Phạm Đoan Trang, and Nguyễn Huyền Trang. Hanoi: Paracel Publishing Housing. Wells-Dang, Andrew. 2010. "Political Space in Vietnam: A View from the 'Rice-Roots."' The Pacific Review 23 (1): 93-111.

Worldometers. 2015. "Viet Nam Population (Live)." Worldometers. Accessed June 7, 2015. http://www.worldometers.info/world-population/vietnam-population/. 


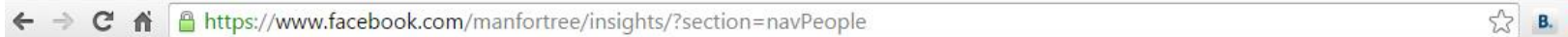

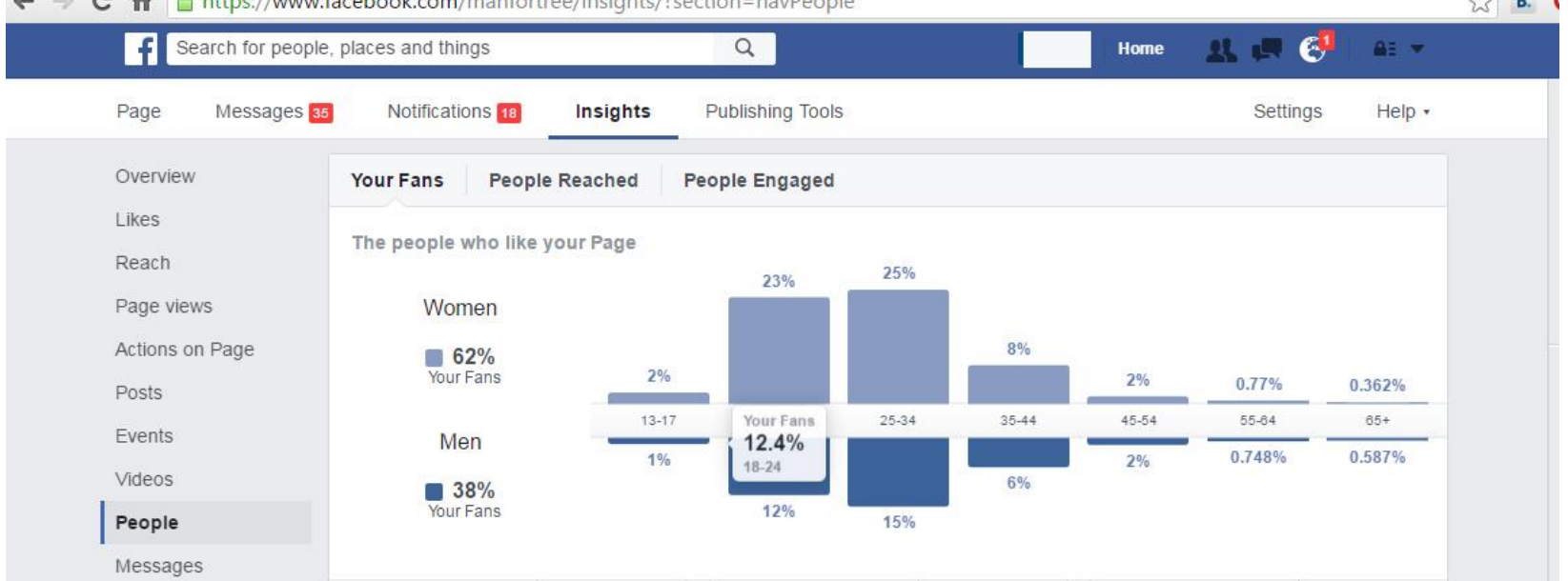

Figure 1. Demographics of the Facebook page 6,700 People for 6,700 Green Trees. (Screenshot taken May 26, 2016 by the page administrator.) 


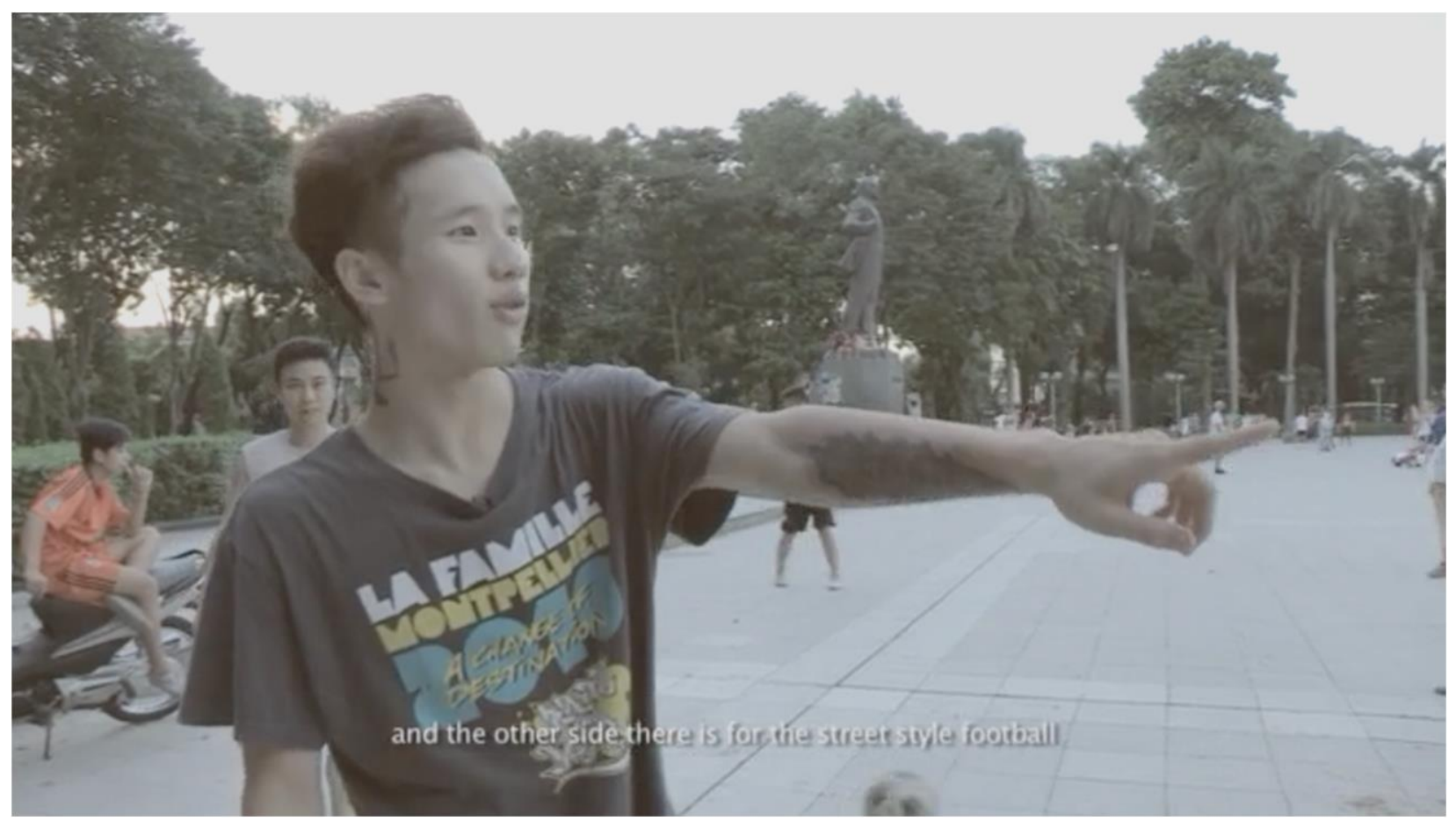

Figure 2. Male student playing freestyle football at Lenin Square explains how the youth groups appropriate space by playing. (Screenshot from an observational video by the research project team; production by Vincent Baumont. The video is viewable at http://www.hanoiyouthpublicspace.com/activities/.) 


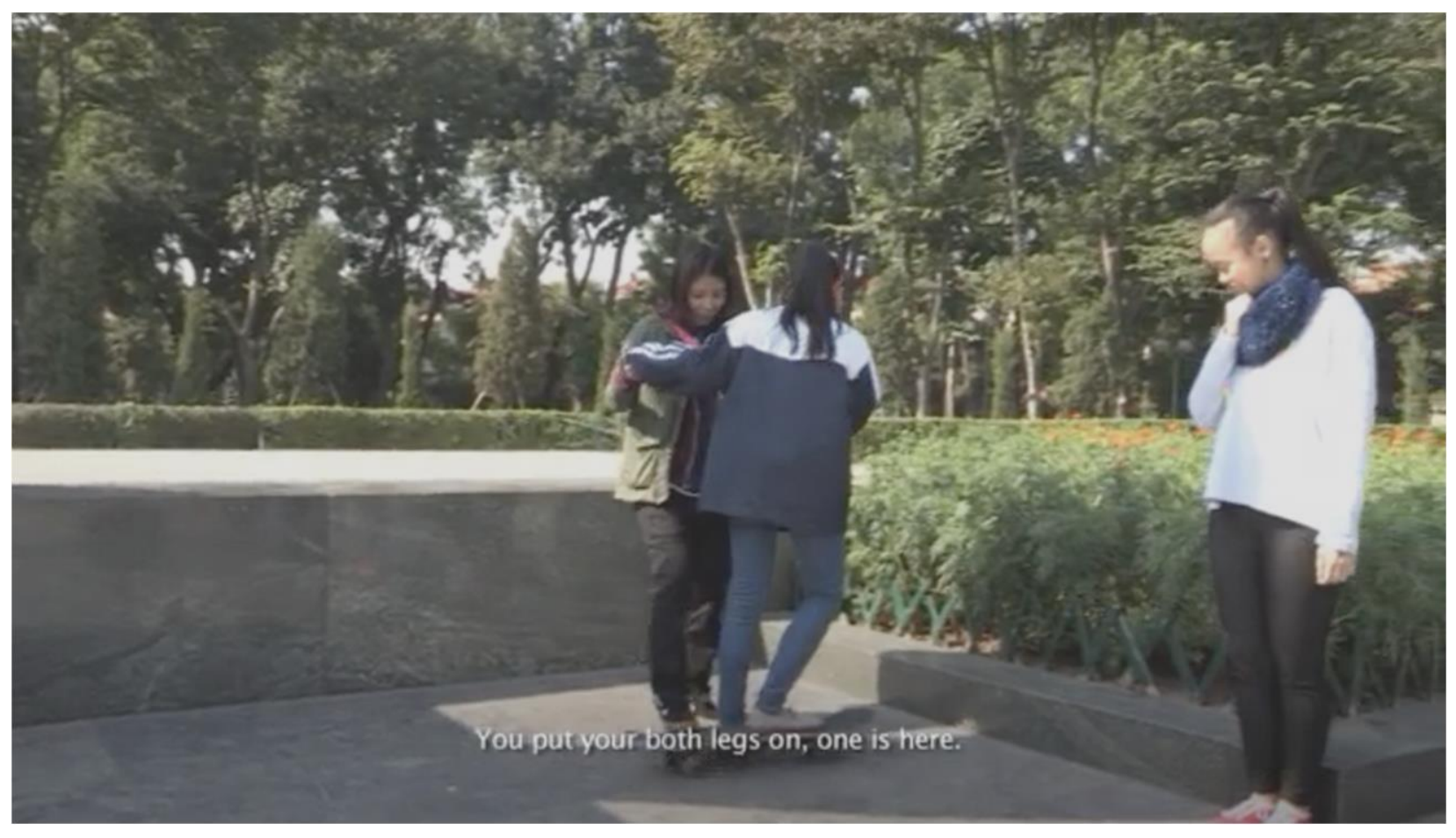

Figure 3. Female student teaching other female students how to skate at Lenin Square.

(Screenshot from an observational video by the research project team; production by Vincent

Baumont. The video is viewable at http://www.hanoiyouthpublicspace.com/gender/.) 


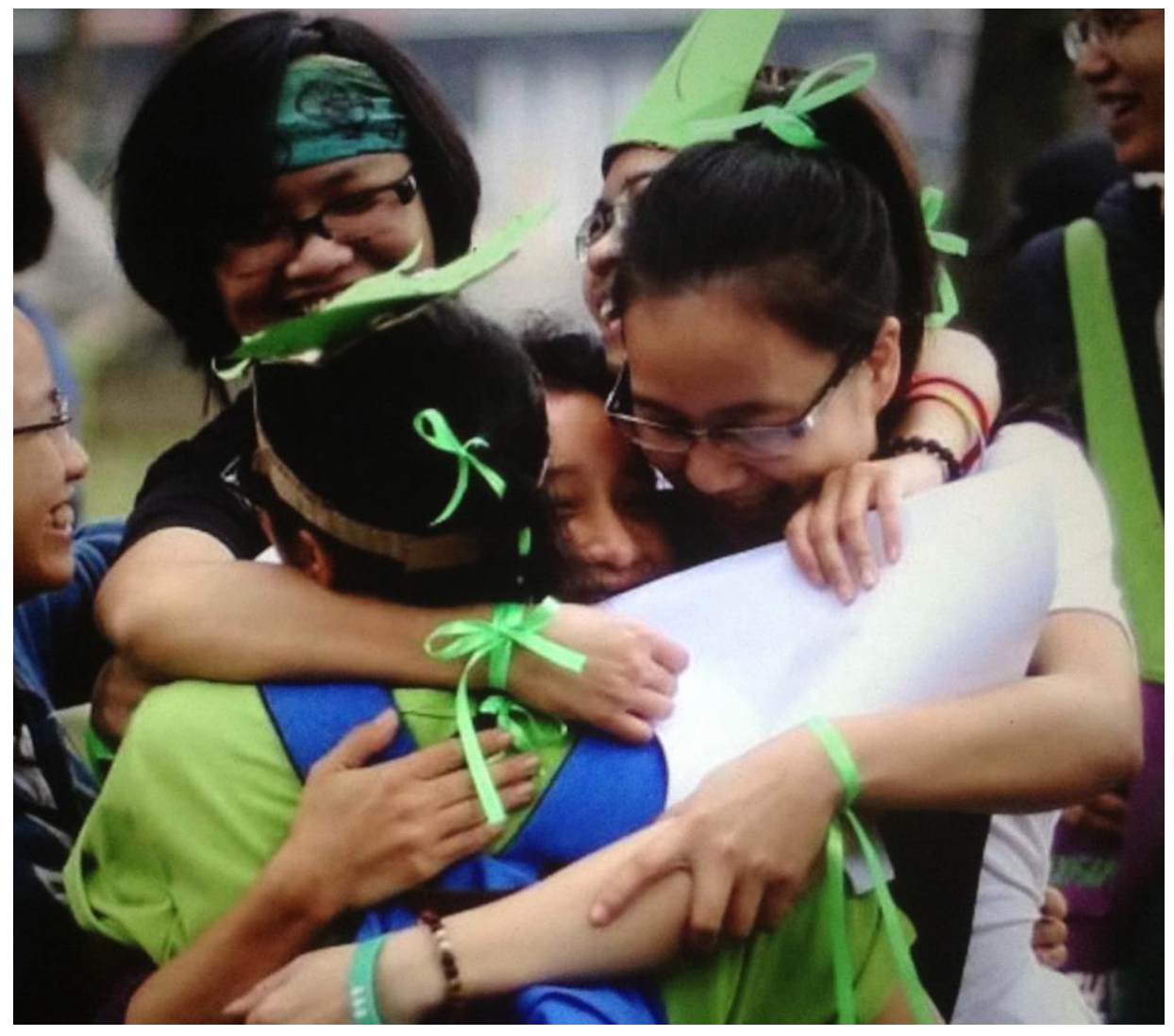

Figure 4. Tree Hug Picnic, March 22, 2015. (Photo: Nguyễn Lân Thắng.) 


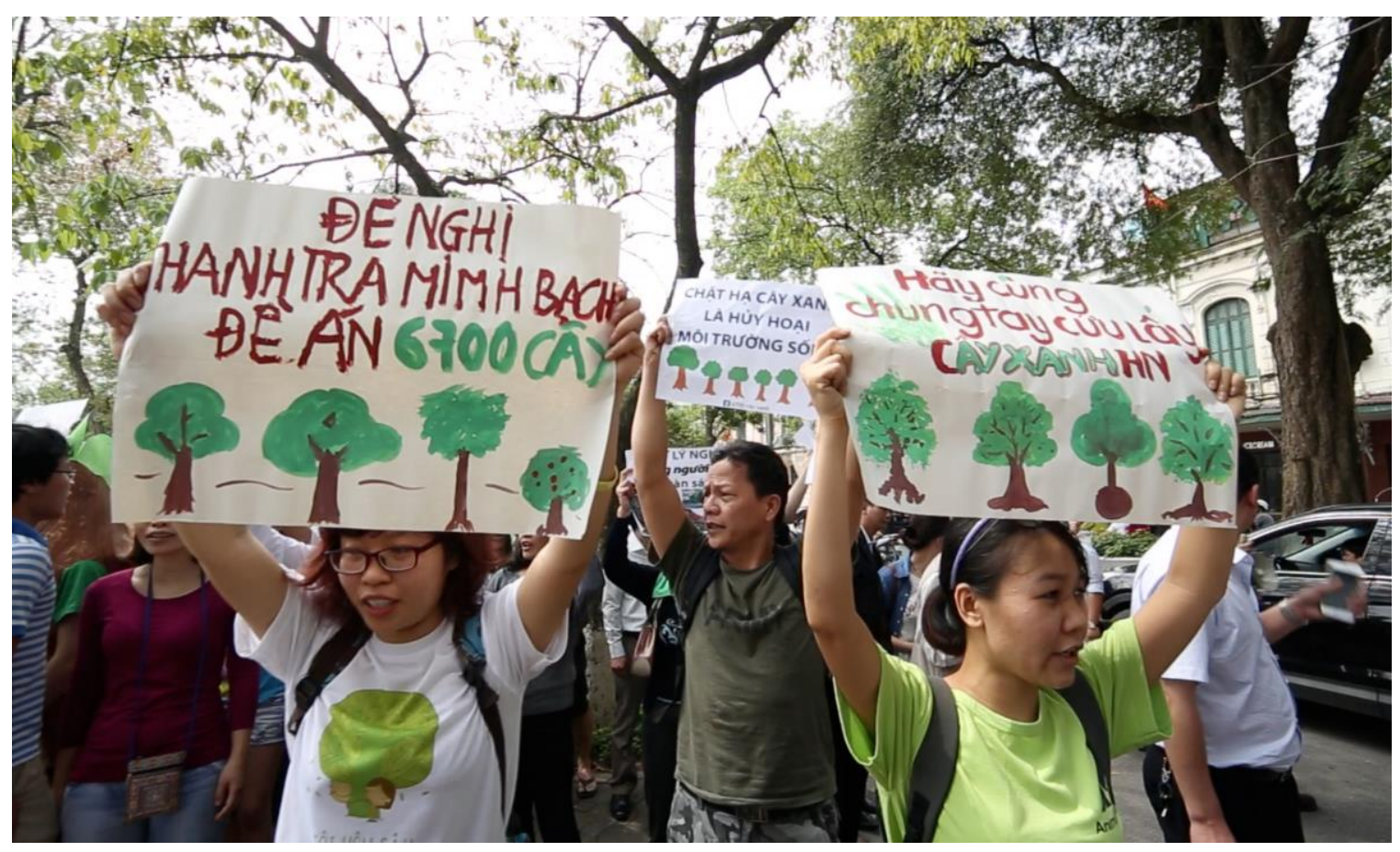

Figure 5. Peaceful Walk, April 12, 2015. (Photo: Đào Thanh Hưng.) 